\title{
Effects of short-term anoxia on benthic denitrification, nutrient fluxes and phosphorus forms in coastal Baltic sediment
}

\author{
Susanna Hietanen ${ }^{1,2, *}$, Kaarina Lukkari ${ }^{3}$ \\ ${ }^{1}$ Department of Biological and Environmental Sciences/Aquatic Sciences, PO Box 65, University of Helsinki, \\ 00014 Helsinki, Finland \\ ${ }^{2}$ Tvärminne Zoological Station, University of Helsinki, 10900 Hanko, Finland \\ ${ }^{3}$ Finnish Institute of Marine Research, PO Box 2, 00561 Helsinki, Finland
}

\begin{abstract}
Whether sediments act as sinks or sources of nutrients depends partly on the oxygen conditions at the seafloor. Laboratory experiments on coastal Gulf of Finland (Baltic Sea) sediment tested the sensitivity of denitrification to a $2 \mathrm{wk}$ anoxia exposure and subsequent reoxidation of the bottom waters. At the same time we followed the rapidly (1 d) and more slowly (9 d) emerging changes in different forms of sediment $\mathrm{P}$ after oxic conditions were restored. The total denitrification rate (Dtot) did not change during anoxic incubation, but shifted from coupled nitrification-denitrification (Dn) towards water column nitrate dependence (Dw). As the Dn rate did not decrease at the same rate as the Dw rate increased, the overall effect of $2 \mathrm{wk}$ exposure to anoxia was an increase in Dtot rate. Nitrification was enhanced in the manipulated sediment compared to natural conditions, despite anoxia. Anoxia quickly caused a release of dissolved P from its 2 most labile forms. The effect was readily reversible, but in nature the replenishment of oxygen stores is usually linked to an intense mixing of the water column, and it is possible that part of the P released during anoxia reaches the productive layer. In our experiments, anoxia affected P cycling more than N cycling.
\end{abstract}

KEY WORDS: Denitrification $\cdot$ Phosphorus fractions $\cdot$ Benthic nutrients $\cdot$ Anoxia

\section{INTRODUCTION}

Eutrophication is one of the main environmental problems in the Baltic Sea. In the most eutrophied part of the sea, the Gulf of Finland, nutrient loading exceeds average loading to the Baltic Sea by a factor of 2 to 3 (Pitkänen et al. 2001). In addition to loading, internal nutrient processing, such as nitrogen (N) removal (by denitrification and anammox) and phosphorus (P) binding to and release from the sediments, define the nutrient status of a water body. Whether sediments act as sinks or sources of nutrients depends partly on the oxygen $\left(\mathrm{O}_{2}\right)$ conditions at the seafloor. Anoxia stops nitrification, an aerobic process oxidizing ammonium to nitrite and nitrate that are reduced to $\mathrm{N}_{2}$ in the anaerobic processes of anammox and denitrification.
As a result, these $\mathrm{N}$ removing processes become limited by the lack of substrate. Consequently, denitrification rates in the Baltic Sea are very low in areas with frequent and prolonged anoxia (Tuominen et al. 1998). $\mathrm{P}$ bound to oxidized iron ( $\mathrm{Fe}$ ) compounds in the sediment can be released as a result of Fe reduction following decrease in $\mathrm{O}_{2}$ concentrations and anoxia (Einsele 1936, Mortimer 1941, 1942). There is a strong correlation between the extent of anoxic sediments and the concentration of dissolved inorganic phosphorus $\left(\mathrm{PO}_{4}{ }^{3-}\right)$ in the Baltic Sea (Conley et al. 2002); the release of sediment $\mathrm{P}$ to the water column (internal $\mathrm{P}$ loading) plays a major role in eutrophication of the Gulf of Finland (Pitkänen et al. 2001). The Baltic Sea continually experiences anoxic episodes of variable frequency and duration (e.g. Laine et al. 1997, Sohle- 
nius et al. 2001, Conley et al. 2002). In the open Gulf of Finland, the replenishment of deep water $\mathrm{O}_{2}$ is mainly regulated by salinity stratification, which is under the influence of irregular salt water intrusions from the western end of the Gulf and freshwater input from the River Neva at the eastern end. In coastal areas, seasonal mixing events restore $\mathrm{O}_{2}$. The $\mathrm{O}_{2}$ level at which harmful effects begin, the rates of reaction responses to changing $\mathrm{O}_{2}$ conditions and the recovery times of system processes when oxic conditions are restored are as yet unclear.

We tested the sensitivity of denitrification to a short term ( $2 \mathrm{wk})$ anoxia exposure and a subsequent reoxidation of bottom waters, a common phenomenon, especially in the coastal areas of the Gulf of Finland in late summer. At the same time the effects of changing $\mathrm{O}_{2}$ conditions on nutrient fluxes across the sedimentwater interface were monitored. We also followed changes in different forms of sediment $\mathrm{P}$ after oxic conditions were restored.

\section{MATERIALS AND METHODS}

Sediment and water. Sediment used in the experiments was collected at the beginning of October 2004 from a coastal station (Gulf of Finland, Tvärminne Storfjärden, $59^{\circ} 51^{\prime} 21^{\prime \prime} \mathrm{N}, 23^{\circ} 15^{\prime} 56^{\prime \prime} \mathrm{E}$ ) representing a characteristic, outer archipelago accumulation bottom consisting of soft mud. Water depth at the sampling station is $33 \mathrm{~m}$. A box corer was used to collect the deeper, reduced sediment and an Ockelman sledge to collect oxidized surface sediment. At the time of the experiments, few macrofauna could be found at the sampling site, probably due to a low-oxygen period in August (Hietanen \& Kuparinen in press). Therefore the mud used was gently sieved ( $1 \mathrm{~mm}$ for the reduced sediment and $0.5 \mathrm{~mm}$ for the surface slurry) to remove the scarce macrozoobenthos so that all subsamples were free of larger animals. Four aquaria (area: $600 \mathrm{~cm}^{2}$, volume: 12 l) were packed with $8 \mathrm{~cm}$ of reduced mud covered with $2 \mathrm{~cm}$ of surface mud and filled with nutrient-free artificial seawater (Reef Crystals [Aquarium Systems] dissolved in distilled water) at a salinity matching that of the sampling location (6 psu). The experiment was conducted at $5^{\circ} \mathrm{C}$ in a cold room. This is the in situ bottom temperature in the study area. Aquaria were left to stabilize under oxic and anoxic conditions (see below) for $12 \mathrm{~d}$ before the first sampling. A similar approach of sieving and mixing sediment has been used in previous experiments with open Baltic Sea sediments (Tuominen et al. 1999). In those experiments (Tuominen et al. 1999), a $\mathrm{NO}_{3}{ }^{-}$peak similar to that occurring in undisturbed samples formed in just $2 \mathrm{~d}$, indicating that the most disturbance-sensitive members of the microbial consortia, the nitrifiers, quickly recovered from the handling of the sediment.

Anoxic-oxic regulation. Aquaria were covered with $5 \mathrm{~mm}$ thick polyacrylic lids. Each was equipped with 2 magnetic stirrers constantly mixing the water phase at the highest possible rate without causing resuspension. Each aquarium lid had a hole for gas bubbling and, in 2 cases, for $\mathrm{O}_{2}$ electrodes. Water phases of 2 of the aquaria were bubbled continually with air through the whole experiment $\left(\mathrm{O}_{2}-\mathrm{O}_{2}\right.$ aquaria). The other 2 aquaria $\left(\mathrm{N}_{2}-\mathrm{O}_{2}\right.$ aquaria) were connected to systems comprising an $\mathrm{O}_{2}$ electrode (Pt-Ag, Strathkelvin Instruments Oxygen Electrode model 1302) immersed in the water phase of each aquarium and connected to an $\mathrm{O}_{2}$ meter (Strathkelvin Instruments Oxygen Meter model 781), which was in turn connected to a regulator (PR Electronics) controlling a magnetic valve (Danfoss) connected to a nitrogen $\left(\mathrm{N}_{2}\right)$ gas bottle. Electrodes were calibrated in artificial seawater (matching the medium in experimental aquaria) subjected to vigorous air bubbling before calibration $\left(100 \% \mathrm{O}_{2}\right.$ saturation) and with $\mathrm{N}_{2}$ gas $\left(0 \% \mathrm{O}_{2}\right.$ saturation). In order to control the level, the regulators were adjusted to $5 \%$ $\mathrm{O}_{2}$ saturation $\left(19 \mu \mathrm{M}=0.4 \mathrm{ml} \mathrm{l}^{-1}\right)$ with $2 \%$ tolerance, so that when $\mathrm{O}_{2}$ concentration in the aquarium increased to $7 \%$ as measured by the electrodes, the regulator opened the magnetic valve to start $\mathrm{N}_{2}$ gas bubbling, and kept it bubbling until $3 \% \mathrm{O}_{2}$ saturation was reached. As the gas supply tubing and the electrode were at the opposing ends of the aquaria, there was a short delay until the entire water phase was mixed and anoxia established at the electrode ends of the aquaria; the system caused $\mathrm{N}_{2}$ bubbling always to proceed until aquaria were completely anoxic. Therefore, the actual $\mathrm{O}_{2}$ saturation in the medium varied between 0 and $7 \%$ (up to $27 \mu \mathrm{M}=0.6 \mathrm{ml} \mathrm{l}^{-1}$ ). Constant mixing with the magnetic stirrers prevented gas and nutrient gradient formation, and the lids reduced $\mathrm{O}_{2}$ diffusion in from the atmosphere, as evidenced by the long pauses between $\mathrm{N}_{2}$ bubbling periods.

Anoxia prevailed in the 2 aquaria for $17 \mathrm{~d}$, with the exception of Day 12, when the $\mathrm{N}_{2}-\mathrm{O}_{2}$ vessels were oxic for 3 to $4 \mathrm{~h}$ due to technical problems while sampling. On Day 18 , the $\mathrm{N}_{2}$ bubbling was replaced with constant air bubbling in order to study process recovery after anoxia.

Nutrients. Samples for measurement of water phase concentrations of nutrients (ammonium $\mathrm{NH}_{4}{ }^{+}$, nitrite + nitrate $\mathrm{NO}_{2}{ }^{-}+\mathrm{NO}_{3}{ }^{-}=\mathrm{NO}_{\mathrm{x}}$, and phosphate $\mathrm{PO}_{4}{ }^{3-}$ ) and sediment denitrification rate were taken on Days 12, 15 (anoxic and oxic), 19 and 27 (oxic). Samples for nutrient analyses $(250 \mathrm{ml})$ were taken from the water phases of all aquaria and replaced with artificial seawater. Nutrients were analyzed using standard methods for seawater (Grasshoff et al. 1983). 
Denitrification. Denitrification was measured using the isotope pairing technique (Nielsen 1992). Two replicate samples were collected from each aquarium in clear plastic cores (diameter $2.6 \mathrm{~cm}$, height $9 \mathrm{~cm}$ ) so that about half of the core was filled with the sediment and half with the water from above. Samples were enriched with potassium nitrate, $\mathrm{K}^{15} \mathrm{NO}_{3} \quad(98 \%$ labelling, Cambridge Isotope Laboratories) to a final concentration of $100 \mu \mathrm{M}^{15} \mathrm{NO}_{3}{ }^{-}$in the water overlying the sediment, then incubated (with a magnetic stirrer on the lids of the cores) at $5^{\circ} \mathrm{C}$ in darkness for 3 to $4 \mathrm{~h}$. Activity in the samples was terminated with $\mathrm{ZnCl}_{2}$, and subsamples were sent in gas-tight $12 \mathrm{ml}$ vials (Exetainer, Labco) to the National Environmental Research Institute, Silkeborg, Denmark for analysis of $\mathrm{N}_{2}$ isotopic composition. Denitrification potential (D15: the denitrification of the added ${ }^{15} \mathrm{NO}_{3}{ }^{-}$) was calculated from the formation of single-labelled $\left({ }^{14} \mathrm{~N}-{ }^{15} \mathrm{~N}\right)$ and double-labelled $\left({ }^{15} \mathrm{~N}-{ }^{15} \mathrm{~N}\right)$ dinitrogen assuming random isotope pairing of the uniformly mixed natural ${ }^{14} \mathrm{NO}_{3}{ }^{-}$ and added ${ }^{15} \mathrm{NO}_{3}{ }^{-}$(Nielsen 1992):

$$
\mathrm{D} 15=\left({ }^{14} \mathrm{~N}^{15} \mathrm{~N}\right)+2\left({ }^{15} \mathrm{~N}^{15} \mathrm{~N}\right)
$$

Naturally occurring denitrification (D14 or Dtot [total denitrification]) based on the unlabelled nitrate available for the denitrifiers was calculated as:

$$
\mathrm{D} 14=\mathrm{D} 15 \times\left[\left({ }^{14} \mathrm{~N}^{15} \mathrm{~N}\right) / 2\left({ }^{15} \mathrm{~N}^{15} \mathrm{~N}\right)\right]
$$

Dtot (D14) can be divided into 'direct' denitrification (based on nitrate available in the water column: Dw) and coupled nitrification-denitrification (Dn: based on nitrate produced in the nitrification process) using the availability of the different nitrate sources as:

$$
\begin{aligned}
\mathrm{Dw}= & \mathrm{D} 15 \times\left[{ }^{14} \mathrm{NO}_{3}{ }^{-}\right] /\left[{ }^{15} \mathrm{NO}_{3}{ }^{-}\right] \\
& \mathrm{Dn}=\text { Dtot }-\mathrm{Dw}
\end{aligned}
$$

where $\left[{ }^{14} \mathrm{NO}_{3}^{-}\right]$and $\left[{ }^{15} \mathrm{NO}_{3}{ }^{-}\right]$represent the concentrations of the naturally occurring ${ }^{14} \mathrm{~N}$ and the added ${ }^{15} \mathrm{~N}$ in the $\mathrm{NO}_{3}^{-}$in the overlying water, respectively (Nielsen 1992).

P fractionation. Two replicate sediment samples for $P$ fractionation studies were collected from each aquarium on Days 19 and 27. Samples were taken in clear plastic cores (see denitrification). The water above the sediment was removed (siphoned) immediately. Samples were capped and kept at $5^{\circ} \mathrm{C}$ in the dark until 2 sediment layers ( 0 to $2 \mathrm{~cm}$ and 2 to $4 \mathrm{~cm}$ ) were separated from each core $\left(\mathrm{O}_{2}-\mathrm{O}_{2}\right.$ treatment immediately; $\mathrm{N}_{2}-\mathrm{O}_{2}$ treatment the following day). $\mathrm{N}_{2}-\mathrm{O}_{2}$ cores were sliced in a $\mathrm{N}_{2}$ atmosphere $\left(\mathrm{O}_{2}\right.$ content $\left.<5 \%\right)$ in a glove box. Subsamples were stored in small plastic bottles at $5^{\circ} \mathrm{C}$. Chemical forms of sediment $\mathrm{P}$ were determined using a slightly modified $\mathrm{P}$ fractionation method by Jensen \& Thamdrup (1993) (detailed description in Lukkari et al. in press). The method separates $6 \mathrm{P}$ pools
(Jensen et al. 1995): (1) loosely adsorbed and porewater $\mathrm{P}$ (extracted with sodium chloride, $\mathrm{NaCl}_{\text {; }}$ referred to hereafter as NaCl-iP), (2) redox-sensitive fraction of $\mathrm{P}$ bound to hydrated oxides of reducible metals (mainly those of $\mathrm{Fe}$ ) (sodium dithionite, $\mathrm{Na}_{2} \mathrm{~S}_{2} \mathrm{O}_{4}$, in bicarbonate buffer $\mathrm{NaHCO}_{3}$ at $\mathrm{pH}$ 7: NaBD-iP), (3) P bound to oxides of non-reducible Fe and aluminium (Al) (inorganic $\mathrm{P}$ in sodium hydroxide, $\mathrm{NaOH}$ : NaOH-iP), (4) apatite-P (hydrochloric acid, $\mathrm{HCl}$ : HCl-iP) and (5) residual, mainly organic, P (extracted with $\mathrm{HCl}$ after combustion: Res-P). The pool of (6) mobile organic P (non-reactive P: NRP) was determined as the difference between total P (TP) and dissolved inorganic P (iP), summarized from the first 3 steps. iP was determined from filtered (Nuclepore polycarbonate membranes, pore size $0.4 \mu \mathrm{m}$ ) extracts by UV-VIS spectrophotometry (Genesys 10uv Thermo Spectronic, with $50 \mathrm{~mm}$ flow injection cuvette) and TP with a spectrophotometer after acid persulphate digestion (Koroleff 1983). Total extractable P (TP $\left.{ }_{\text {extr }}\right)$, calculated as the sum of all steps, is 90 to $95 \%$ of total P content in the sediment $\left(\mathrm{TP}_{\text {sed }}\right)$ determined after strong digestion (with aqua regia, fluoric acid and boric acid).

Sediment dry mass (DM) was first determined using a moisture analyzer (balance equipped with a halogen lamp dryer: Ohaus MB45) and the amount of fresh sediment extracted was determined as a fresh weight corresponding to $0.3 \mathrm{~g}$ DM. The volume of the extracts was always $30.0 \mathrm{ml}$, yielding a sediment DM-tosolution ratio of 1:100. Extraction was made at room temperature (on orbital shaker table) and during the first 2 steps (NaCl-iP and $\mathrm{NaBD}-\mathrm{iP}$ ) samples were handled in a $\mathrm{N}_{2}$ atmosphere $\left(\mathrm{O}_{2}<5 \%\right)$ in a glove box. Supernatants were separated by centrifugation $(3362 \times g, 15 \mathrm{~min})$ and extraction solutions and following rinsing solutions were combined into 1 sample in each step. Samples were preserved with sulphuric acid ( $\mathrm{pH} 2$, except those already containing acid) after filtration and stored at $5^{\circ} \mathrm{C}$ until analyses.

Statistical analyses. The results from the 2 aquaria per treatment were combined (independent variables: 2 treatments, 2 aquaria per treatment, 2 replicates per aquarium and different times). Differences in rates of Dtot, Dn, and Dw were tested ( $t$-tests, 2 sample assuming equal variances) between anoxic and oxic aquaria on each sampling occasion. Paired $t$-tests were used to evaluate the significance of the changes from one sampling occasion to the next. D15 based on the added ${ }^{15} \mathrm{NO}_{3}{ }^{-}$was analysed similarly. The significances of differences between concentrations of $\mathrm{P}$ fractions were tested on Days 19 and 27 within a treatment (paired $t$-test) and between treatments ( $t$-test, 2 sample assuming unequal variances). For all tests, the significance level adopted was $\mathrm{p}<0.05$. 


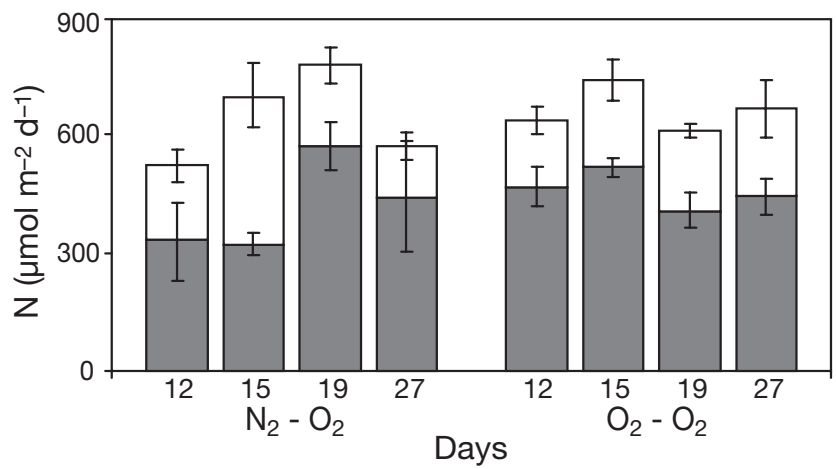

Fig. 1. Denitrification ( $\mu$ mol $\mathrm{N} \mathrm{m}^{-2} \mathrm{~d}^{-1}$; mean $\pm \mathrm{SD}$ ). Grey columns: coupled nitrification-denitrification (Dn); white columns: denitrification based on water column nitrate (Dw). $\mathrm{N}_{2}-\mathrm{O}_{2}$ aquaria anoxic until Day 17, thereafter oxic; $\mathrm{O}_{2}-\mathrm{O}_{2}$ aquaria experiencing only oxic conditions

\section{RESULTS}

\section{Denitrification}

Denitrification rates in the aquaria were high, averaging $650 \mu \mathrm{mol} \mathrm{N} \mathrm{m}{ }^{-2} \mathrm{~d}^{-1}$ (Fig. 1). On the first sampling on Day 12, no significant differences were found between the oxic and anoxic aquaria. From Day 12 to Day 15, Dtot (sum of Dn and Dw) and Dw (but not Dn) increased significantly in oxic and anoxic aquaria. There were significant differences in Dw and Dn between the treatments (Dw higher in anoxic, Dn higher in oxic), but not in Dtot rates. Oxic conditions were restored in $\mathrm{N}_{2}$ $\mathrm{O}_{2}$ aquaria on Day 17. From Day 15 to Day 19, the rates of Dw decreased and Dn increased significantly in the $\mathrm{N}_{2}-\mathrm{O}_{2}$ aquaria, and Dn decreased in the $\mathrm{O}_{2}-\mathrm{O}_{2}$ aquaria. Dtot and Dn (but not Dw) were significantly higher in the $\mathrm{N}_{2}-\mathrm{O}_{2}$ than in the $\mathrm{O}_{2}-\mathrm{O}_{2}$ aquaria on Day 19. From Day 19 to Day 27, only the Dw rate in $\mathrm{N}_{2}-\mathrm{O}_{2}$ aquaria decreased significantly, while other rates remained at the same level, and no differences between the treatments were found thereafter.

D15 doubled from Day 12 to Day 15 in the $\mathrm{N}_{2}-\mathrm{O}_{2}$ aquaria, but decreased back to the average level (300 umol $\mathrm{N} \mathrm{m}^{-2} \mathrm{~d}^{-1}$ ) by Day 19 when oxic conditions had been restored. There were no differences in D15 rates between Days 19 and 27 in the $\mathrm{N}_{2}-\mathrm{O}_{2}$ aquaria. In the $\mathrm{O}_{2}-\mathrm{O}_{2}$ aquaria, there were no differences in the D15 rates between days. The average level did not differ from the D15 rates in $\mathrm{N}_{2}-\mathrm{O}_{2}$ aquaria except on Day 15.

\section{Nutrients}

Nutrient dynamics clearly differed between the oxic and anoxic aquaria. As the water added to the aquaria was initially nutrient free (analysed at the beginning of the experiment and each time when added to the aquaria; average concentrations were $\mathrm{NH}_{4}{ }^{+}: 0.33 \mu \mathrm{M}$, $\left.\mathrm{NO}_{\mathrm{x}}: 1.09 \mu \mathrm{M}, \mathrm{PO}_{4}{ }^{3-}: 0.03 \mu \mathrm{M}\right)$, all nutrients in the water column originated from the sediment. Both $\mathrm{NH}_{4}{ }^{+}$ and $\mathrm{PO}_{4}{ }^{3-}$ occurred at high concentrations during anoxia, but after the shift from anoxic to oxic conditions they quickly decreased to the same low level measured in the oxic aquaria (Fig. 2). In contrast, while $\mathrm{NO}_{\mathrm{x}}$ concentrations were higher in oxic than in anoxic aquaria (and were remarkably high in general), the difference was not especially marked, and there was no clear change in concentration after the shift from anoxic to oxic conditions (Fig. 2).

\section{$P$ fractionation}

Concentration of the $\mathrm{TP}_{\text {extr }}$ was about $54 \mu \mathrm{mol}$ $(g \mathrm{DM})^{-1}$ at the surface $(0$ to $2 \mathrm{~cm}$ ) and $35 \mu \mathrm{mol}$ $(\mathrm{g} \mathrm{DM})^{-1}$ in the deeper $(2$ to $4 \mathrm{~cm}$ ) layer. The NaBD-iP
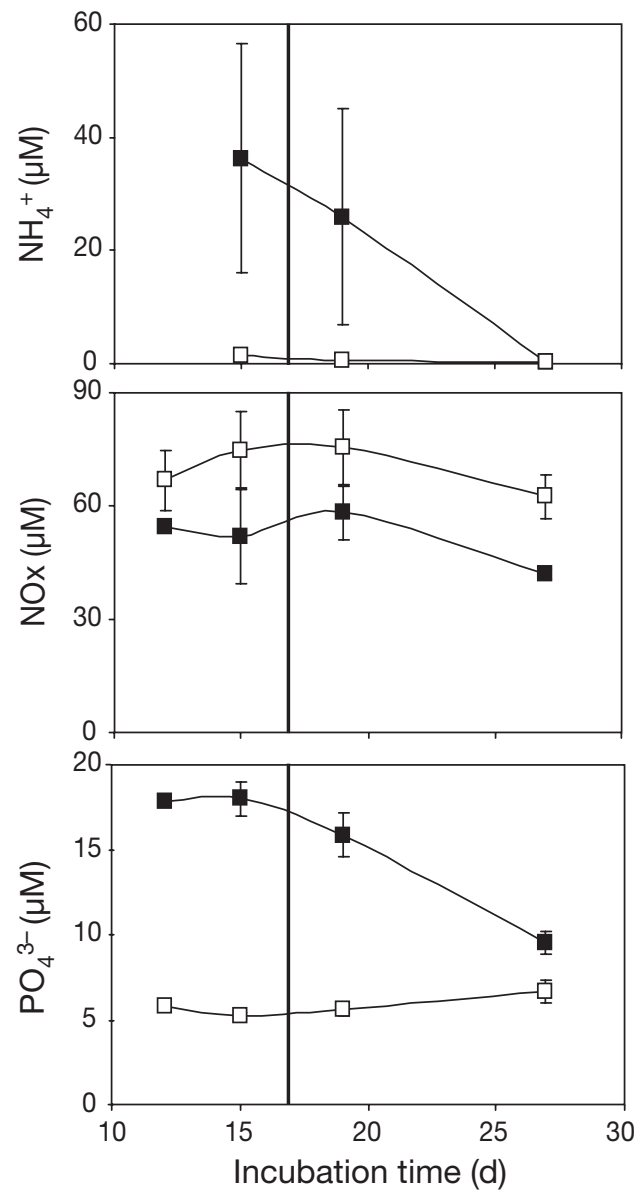

Fig. 2. Nutrient concentrations $\left(\mu M_{;}\right.$mean $\left.\pm S D\right)$. $\mathbf{a}$ : aquaria anoxic until Day 17, thereafter oxic; $\square$ : aquaria experiencing only oxic conditions. The vertical line shows the timing of the shift from anoxic to oxic conditions 

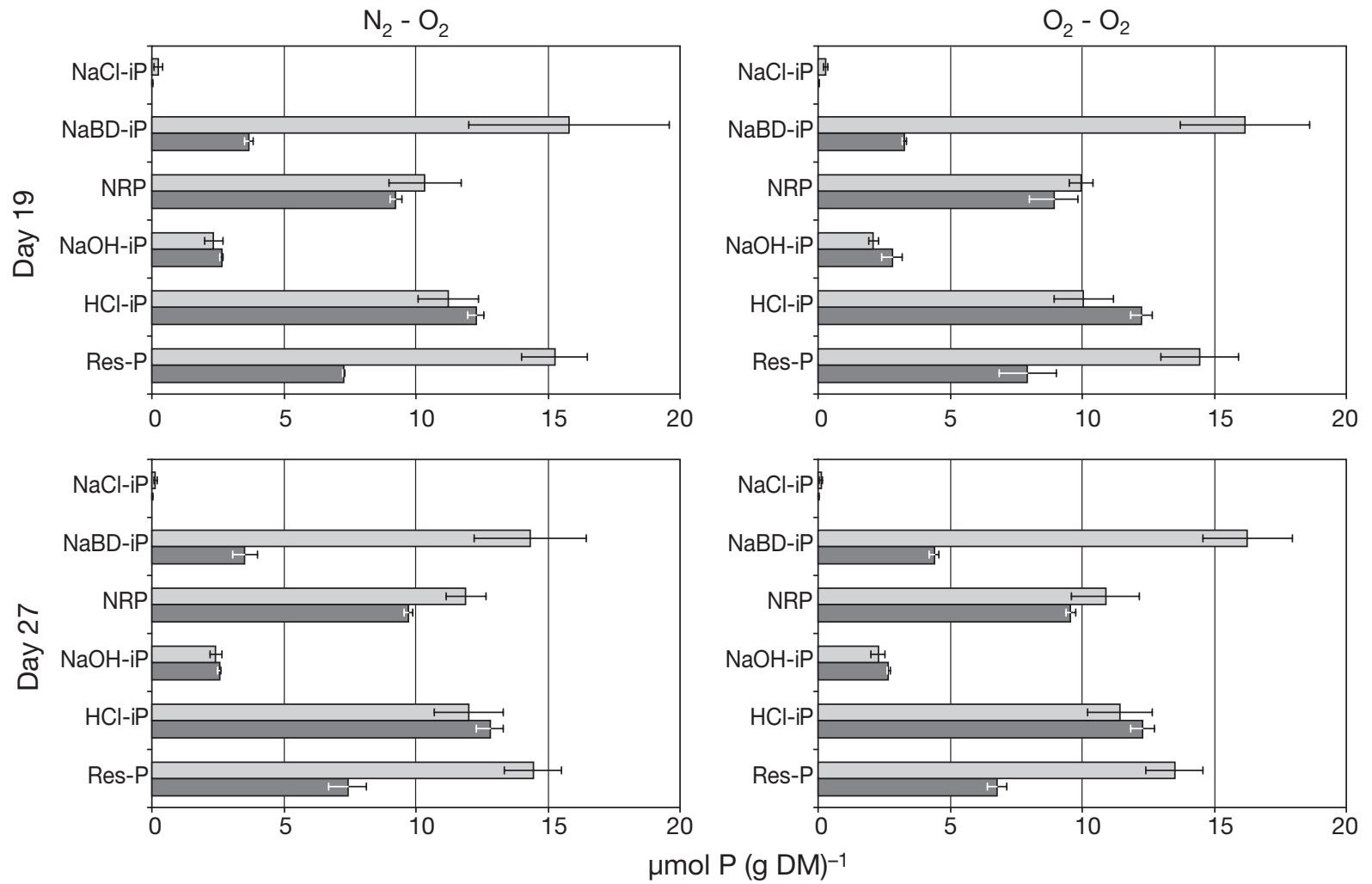

Fig. 3. $\mathrm{P}$ fractions $\left(\mu \mathrm{mol} \mathrm{P}(\mathrm{g} \mathrm{DM})^{-1}\right.$; mean $\pm \mathrm{SD}$ ) in 0 to $2 \mathrm{~cm}$ (light grey) and 2 to $4 \mathrm{~cm}$ (dark grey) sediment layers on sampling Days 19 and 27. For description of different fractions, see text

fraction formed the major part of TP in the surface layer, followed by Res-P; in the deeper layer, HCl-iP and NRP were the most abundant and second most abundant fractions, respectively (Fig. 3).

$\mathrm{NaCl}-\mathrm{iP}$ was the smallest $\mathrm{P}$ fraction, forming $<1 \%$ of the $\mathrm{TP}_{\text {extr. }} \mathrm{NaCl}-\mathrm{iP}$ was slightly (but significantly) higher in $\mathrm{O}_{2}-\mathrm{O}_{2}$ than in $\mathrm{N}_{2}-\mathrm{O}_{2}$ aquaria on Day 19 . Decrease in $\mathrm{NaCl}-\mathrm{iP}$ with time in both layers of the $\mathrm{O}_{2}-\mathrm{O}_{2}$ aquaria was small, but statistically significant, whereas no change was detected in the $\mathrm{N}_{2}-\mathrm{O}_{2}$ aquaria. On Day 27, there were no significant differences in $\mathrm{NaCl}-\mathrm{iP}$ between the 2 treatments.

NaBD-iP formed about 30 and $10 \%$ of the $\mathrm{TP}_{\text {extr }}$ in the surface and deeper layers, respectively. On Day 19, NaBD-iP was significantly higher in the deeper layer of the $\mathrm{N}_{2}-\mathrm{O}_{2}$ aquaria (even though the difference was small), whereas it was higher in the surface layer of the $\mathrm{O}_{2}-\mathrm{O}_{2}$ aquaria (not significantly so, possibly because of the high variances). Between Days 19 and 27, NaBD-iP remained at the same concentration in the surface layer of the $\mathrm{O}_{2}-\mathrm{O}_{2}$ aquaria, but increased significantly in the deeper layer. No significant differences between the treatments were found on Day 27.

The share of the NRP fraction was slightly higher in the deeper layer (26\%) than in the surface layer (19\%), and it increased in both layers in all aquaria during the experiment. In $\mathrm{N}_{2}-\mathrm{O}_{2}$ aquaria, the increase was statis- tically significant in both depth layers. On both sampling days, $\mathrm{N}_{2}-\mathrm{O}_{2}$ aquaria had higher NRP concentrations than $\mathrm{O}_{2}-\mathrm{O}_{2}$ aquaria, but the differences were not significant.

Of the immobile fractions, $\mathrm{NaOH}$-iP formed about 4 and $8 \%$ of the $\mathrm{TP}_{\text {extr }}$ in surface and deeper layers, respectively, and did not vary significantly between sampling times or treatments. HCl-iP formed about 20 and $35 \%$ of the $\mathrm{TP}_{\text {extr }}$ in the surface and deeper layers, respectively. Its concentration increased in the surface layer of all aquaria from Day 19 to Day 27, but the increase was not significant. Res-P fraction was slightly more abundant in the surface (about $27 \%$ ) than in the deeper (about $21 \%$ ) layer and its share decreased, but not significantly, during the experiment. There were no significant differences between the treatments despite the slightly higher concentration in the $\mathrm{N}_{2}-\mathrm{O}_{2}$ aquaria.

\section{DISCUSSION}

\section{Nitrification and denitrification}

The total denitrification rates were found to be less sensitive to $\mathrm{O}_{2}$ deficiency than we expected. Denitrification based in the water column $\mathrm{NO}_{\mathrm{x}}$ (Dw) was 
removing $\mathrm{NO}_{\mathrm{x}}$ directly from the water phase of the aquaria at a rate of about $12 \mu \mathrm{mol} \mathrm{N}$ aquarium ${ }^{-1} \mathrm{~d}^{-1}$, except on Day 15, when the removal rate doubled in anoxic aquaria. In addition, the coupled nitrificationdenitrification used about $27 \mu \mathrm{mol} \mathrm{N}$ aquarium ${ }^{-1} \mathrm{~d}^{-1}$. Thus, denitrification was removing $\mathrm{NO}_{\mathrm{x}}$ at a rate of about $40 \mu \mathrm{mol} \mathrm{N}$ aquarium ${ }^{-1} \mathrm{~d}^{-1}$, and nitrification must have produced $\mathrm{NO}_{\mathrm{x}}$ at least at the same rate as there was no clear decrease in $\mathrm{NO}_{\mathrm{x}}$ concentrations (averaging $60 \mu \mathrm{M}, 300 \mu \mathrm{mol}$ aquarium $^{-1}$ ) between Days 12 and 27.

The $\mathrm{O}_{2}$ concentration during the 'anoxic' incubation period stayed below $7 \%\left(27 \mu \mathrm{M}=0.6 \mathrm{ml} \mathrm{l}^{-1}\right)$, with a short exposure to $\mathrm{O}_{2}$ in the setting up of the experiments and during the first sampling. When filling the aquaria with artificial sea water at the onset of the experiments, $\mathrm{NH}_{4}{ }^{+}$probably leaked from the porewater of the surface sediment to the originally nutrient-free water, despite all the care that was taken to prevent mixing of the sediment with the water (to the eye, there was virtually no mixing). The sampling further released $\mathrm{NH}_{4}{ }^{+}$from the sediment to the water. The short exposures ( 4 to $5 \mathrm{~h}$ at the onset and during the first sampling) to $\mathrm{O}_{2}$ clearly provided the nitrifying bacteria with enough $\mathrm{O}_{2}$ to oxidize $\mathrm{NH}_{4}{ }^{+}$released from the sediment, as shown by the high concentrations of $\mathrm{NO}_{\mathrm{x}}$ during the experiment, despite anoxia in the 2 aquaria. The small difference between the $\mathrm{NO}_{\mathrm{x}}$ concentrations in the oxic and anoxic aquaria was reflected in the higher concentration of $\mathrm{NH}_{4}{ }^{+}$in the anoxic aquaria. Nitrifiers have a high affinity for $\mathrm{O}_{2}$ and the minimum concentration at which nitrification still proceeds can be as low as $2 \mu \mathrm{M} \mathrm{O}_{2}\left(0.05 \mathrm{ml} \mathrm{l}^{-1}\right)$ (Gundersen 1966, Gundersen et al. 1966, Carlucci \& McNally 1969, Henriksen \& Kemp 1988). Indeed, nitrification is often fastest in sub-saturating oxygen conditions (Goreau et al. 1980, Prosser 1989, Voytek \& Ward 1995a,b, Kester et al. 1997). However, in Chesapeake Bay, the nitrification rate is minimal at just below $125 \mu \mathrm{M} \mathrm{O}_{2}$ concentration; sediment $\mathrm{O}_{2}$ consumption in this system exceeds $\mathrm{O}_{2}$ diffusion into the sediment and restricts nitrification to the sediment surface (Kemp et al. 1990). In our experiments, the dominant nitrate source for denitrification shifted from coupled nitrification-denitrification towards more water column $\mathrm{NO}_{\mathrm{x}}$ dependence during the anoxic incubations. This indicates that nitrification in the anoxic aquaria did not cease but concentrated in a shallower layer closer to the sediment surface leading to nitrate diffusion into the water column and uncoupling from denitrification. Clearly, nitrification dynamics cannot be predicted from the $\mathrm{O}_{2}$ concentrations alone, but sediment $\mathrm{O}_{2}$ consumption plays a role in defining the depth at which nitrification is still possible. In addition, an earlier exposure to low $\mathrm{O}_{2}$ concentrations or even anoxia causes adaptations in nitrifying communities, so that bacteria repeatedly experiencing such conditions have a higher affinity for $\mathrm{O}_{2}$ than bacteria from permanently oxic environments (Bodelier et al. 1996). During anoxic periods, bacteria in fluctuating $\mathrm{O}_{2}$ environments conserve their capacity to nitrify, and are therefore able to react immediately to improved $\mathrm{O}_{2}$ availability (Bodelier et al. 1996).

As the incubation cores used in the denitrification measurements were not gas-tight, $\mathrm{O}_{2}$ was also diffusing into the cores during the 3 to $4 \mathrm{~h}$ incubation times. This diffusion is $50 \mu \mathrm{M} \mathrm{O}_{2} \mathrm{~h}^{-1}$ at $90 \mu \mathrm{M} \mathrm{O}_{2}$ concentration in the water overlying the sediment (Hietanen \& Kuparinen in press). According to Fick's first law, diffusion was faster at the lower $\mathrm{O}_{2}$ concentration used in these experiments. Therefore, it is also possible that some $\mathrm{NH}_{4}{ }^{+}$was oxidized to $\mathrm{NO}_{\mathrm{x}}$ in the cores during the incubation. However, the ambient $\mathrm{NO}_{\mathrm{x}}$ concentration in the aquaria (and consequently in the incubation cores) was so high that nitrification during incubation would have made no significant difference to the measured denitrification rates. The diffusion of $\mathrm{O}_{2}$ into the cores and its subsequent consumption are also unlikely to have increased the $\mathrm{O}_{2}$ concentration in the cores so quickly that it would have affected the depth of the denitrifying layer through increased $\mathrm{O}_{2}$ penetration depth or changed the overall microbial activity in the cores.

D15 reflects Dw at unlimited $\mathrm{NO}_{\mathrm{x}}$ concentration. D15 and Dw doubled in the anoxic aquaria from Day 12 to Day 15 . The increase may have been caused by a switch from oxic to anoxic metabolism in the facultatively anaerobic bacteria as the oxidized layer in the sediment became thinner. It may also be due to the possible uncoupling of nitrification and denitrification, as nitrification concentrated closer to the sediment surface and subsequently nitrate diffused into the water. However, as the Dn rate did not decrease at the same rate as the Dw rate increased, the overall effect of the 2 wk exposure to anoxia was an increase in the Dtot rate.

\section{Anammox}

In addition to denitrification, another $\mathrm{N}$ removing process, anaerobic oxidation of ammonium (anammox), has recently been found active in marine sediments (e.g. Thamdrup \& Dalsgaard 2002, Dalsgaard \& Thamdrup 2002, Trimmer et al. 2003). In this process, microbes oxidize $\mathrm{NH}_{4}{ }^{+}$with $\mathrm{NO}_{2}{ }^{-}$to form $\mathrm{N}_{2}$. Accumulating knowledge about the process and the responsible microbes was reviewed by Dalsgaard et al. (2005). In marine sediments, both $\mathrm{N}$ removing processes can proceed at the same time, which complicates the calcu- 
lations based on the added ${ }^{15} \mathrm{~N}$-label (e.g. RisgaardPetersen et al. 2003, 2004). In a recent study, anammox was found to contribute 10 to $15 \%$ to the total $\mathrm{N}_{2}$ formation at our study site (Hietanen \& Kuparinen in press). Anammox was not directly measured in the present study, but the effect of a 10 to $15 \%$ contribution of anammox on the results can be calculated according to Risgaard-Petersen et al. (2003, 2004; equations 15, 21 and 24). A share of $10 \%$ would overestimate Dtot by $2.5 \%$ in all but the anoxic samples, for which it would cause 4 and $6 \%$ overestimates of $\mathrm{N}_{2}$ production on Days 12 and 15, respectively. A share of $15 \%$ would overestimate Dtot by $5 \%$ in all but the anoxic samples, for which it would cause 7 and $10 \%$ overestimates of $\mathrm{N}_{2}$ production on Days 12 and 15, respectively. Interestingly, the higher error in the $\mathrm{N}_{2}$ $\mathrm{O}_{2}$ incubations during anoxic incubation decreased to the level in the oxic aquaria by Day 19, i.e. $1 \mathrm{~d}$ after the switch from anoxic to oxic conditions. The overestimations were not statistically significant in any case (t-test, p > 0.05).

\section{Phosphorus cycling}

The oxidation and reduction reactions of Fe and subsequent release and binding of $\mathrm{P}$ from and to the hydrated oxides of Fe occur relatively quickly (Davison \& Seed 1983, Millero et al. 1987). Thus, we expected that fluctuating $\mathrm{O}_{2}$ conditions would quickly affect the sediment $\mathrm{P}$ fractions, mainly those representing dissolved or loosely bound $\mathrm{P}(\mathrm{NaCl}-\mathrm{iP})$ and $\mathrm{P}$ bound to reducible Fe-compounds (NaBD-iP). The first samples were taken when oxic conditions had prevailed for $1 \mathrm{~d}$ after the exposure to anoxia. The effect of anoxia could was still evident in the smaller $\mathrm{NaCl}$-iP fraction in the previously anoxic aquaria, in which the reduced conditions had caused $\mathrm{P}$ release from sediment to the pore water and further diffusion to the overlying water (Krom \& Berner 1980, Gächter et al. 1988, Hupfer \& Uhlmann 1991, Gunnars \& Blomqvist 1997). The water column $\mathrm{PO}_{4}{ }^{3-}$ concentrations were also higher in the aquaria that had suffered from anoxia. On the other hand, no sign of the release of Fe-bound P (NaBD-iP) from the sediment was evident in the previously anoxic aquaria $1 \mathrm{~d}$ after the switch. Andersen \& Ring (1999) reported that during long-term anaerobic incubation, most loss of sediment $\mathrm{P}$ occurred in the Fe-bound $\mathrm{P}$ fraction. In our study, however, given the fast oxidation of $\mathrm{Fe}^{2+}$ to $\mathrm{Fe}^{3+}$ (Davison \& Seed 1983, Millero et al. 1987), one day of oxic conditions was probably sufficient for capture of the released $\mathrm{P}$ back to the sediment surface; this was also evident from the quickly decreasing concentrations of $\mathrm{PO}_{4}{ }^{3-}$ in the water columns of the aquaria. Similar sorption of $\mathrm{PO}_{4}{ }^{3-}$ from the water column to the sediment during a positive redox-shift in laboratory experiments has been described by Gächter et al. (1988), Hupfer \& Uhlmann (1991) Gunnars \& Blomqvist (1997) and others. In addition, NaBD-iP did not increase in the previously anoxic aquaria between Days 19 and 27; $9 \mathrm{~d}$ after restoring the oxic conditions, there was no significant difference in sediment NaBD-iP fractions between the treatments. Time had no effect on the amount of Fe-bound P in the surface layers of the oxic aquaria, which indicates that oxic incubation did not cause remobilization of NaBDiP from the deeper to the surface layer. Instead, the increase of NaBD-iP in the deeper layer of the oxic aquaria towards Day 27 could have been caused by the prolonged exposure of the deeper layer to $\mathrm{O}_{2}$ diffusion into the sediment (resulting from sediment disturbance during sampling). The slight decrease with time of $\mathrm{NaCl}-\mathrm{iP}$ in the oxic treatment may have been caused by a slow diffusion of $\mathrm{P}$ from the pore water to the water column, where $\mathrm{PO}_{4}{ }^{3-}$ increased with time as well. Similar decrease of NaCl-iP with time did not occur in the previously anoxic aquaria, probably because the release of $\mathrm{PO}_{4}{ }^{3-}$ to the water column had already occurred at the beginning of the experiment. After the shift from anoxic to oxic conditions, the sediment started to oxidize and bind P more efficiently. By Day 27, the conditions had stabilized and there was no difference between treatments in $\mathrm{NaCl}$-iP fractions.

The organic forms of sediment $\mathrm{P}$ (the more labile NRP and the more recalcitrant Res-P) also showed changes during the experiment, but these forms were not affected as clearly and quickly as the 2 most mobile $\mathrm{P}$ forms discussed above. Generally, NRP seemed to increase with time, while Res-P seemed to decrease and both fractions were higher in the anoxic treatment. However, the only statistically significant difference in these fractions was the increase of NRP with time in the anoxic treatment. The Res-P fraction is commonly included in the immobile forms of P (e.g. Jensen et al. 1995), but due to its organic nature, its composition and therefore its degradability vary depending on the deposited material and the prevailing conditions in the sediment. It is possible that part of the Res-P was degraded or transformed into more mobile P forms, but this cannot be confirmed with our results, and it is not clear whether the incubation time was long enough for such transformations. The $\mathrm{NaOH}$-extractable NRP is not solely organic, but contains compounds formed in biological transformations, such as pyrophosphate (a degradation product of organic P) and polyphosphate, a storage compound of $\mathrm{P}$ found in many microorganisms (Hupfer et al. 1995a, Ahlgren et al. 2005). Microbial $\mathrm{PO}_{4}{ }^{3-}$ binding and polyphosphate synthesis in the sediment as well as release during changing $\mathrm{O}_{2}$ conditions have been reported by Gächter et al. (1988) and 
Hupfer \& Uhlmann (1991). The increase in NRP in this experiment is in accordance with these earlier findings. Törnblom \& Rydin (1998) reported a close relationship between increased $\mathrm{NaOH}$-extractable NRP and bacterial biomass as a result of seston addition to sediment in a 3 wk experiment. Furthermore, Hupfer et al. (2004) found that in aerobic conditions, $46 \%$ of the added $\mathrm{P}$ was incorporated to form NaBD-iP and $36 \%$ to NaOH-NRP, and that polyphosphate was synthesized. If part of the organic $\mathrm{P}$ in our samples were degraded or transformed, dissolved $\mathrm{PO}_{4}{ }^{3-}$ could have been released, increasing the pool of $\mathrm{P}$ in pore-water, $\mathrm{P}$ bound to oxidized Fe-compounds, or $\mathrm{P}$ in the water column (e.g. Krom \& Berner 1980).

The 2 most inert $\mathrm{P}$ fractions ( $\mathrm{NaOH}-\mathrm{iP}$ and $\mathrm{HCl}-\mathrm{iP}$ ) did not show any marked changes in either of the treatments, as expected (Psenner et al. 1984, Jensen \& Thamdrup 1993). In natural conditions, these forms are most likely buried with sediment, removing $\mathrm{P}$ from the short-term nutrient cycle. However, resuspension of the surface sediment into water column with higher $\mathrm{pH}$ (e.g. due to intensive algal production) could liberate oxide-bound P (NaOH-iP) (Drake \& Heaney 1997).

\section{Effects of seasonal anoxia in the coastal Gulf of Finland}

In our experiments, the shift from oxic conditions to anoxia in the water column was very sudden (only a matter of minutes), whereas in nature the $\mathrm{O}_{2}$ concentration decreases more slowly in the course of days or even weeks, leaving the microbes time to adjust to changing conditions. In contrast, the reoxidizing of the bottom waters in the study area happens relatively quickly as a result of the autumn water column turnover, and the response in the processes is probably as fast in nature as it was in the experiments reported here. According to our results, the nitrification-denitrification system in the study area is highly flexible, and denitrification proceeds unaffected for at least $2 \mathrm{wk}$ after the onset of anoxia. However, in the laboratory experiments, which were done with homogenised, sieved sediments, both the denitrification rates and the $\mathrm{NO}_{\mathrm{x}}$ concentrations were extremely high. In a yearround survey in the area where the sediment for the experiments was collected, the highest $\mathrm{NO}_{\mathrm{x}}$ concentration in the near-bottom water and the fastest denitrification rate measured were $3 \mu \mathrm{M}$ and approximately $400 \mu \mathrm{mol} \mathrm{N} \mathrm{m}{ }^{-1} \mathrm{~d}^{-1}$ (Hietanen \& Kuparinen in press), respectively, compared to $60 \mu \mathrm{M}$ and $650 \mu \mathrm{mol} \mathrm{N} \mathrm{m}{ }^{-1}$ $\mathrm{d}^{-1}$, respectively, in the experiments reported here. Nevertheless, in our experiments, all of the $\mathrm{NO}_{\mathrm{x}}$ was produced by nitrification, which clearly was enhanced compared to natural conditions, despite the anoxia. A likely explanation for the enhanced nitrification is the increased availability of $\mathrm{NH}_{4}{ }^{+}$(released during the setting up of the experiments and in sampling) combined with a thick $(2 \mathrm{~cm})$ oxidized layer, enabling nitrification to proceed, even during the anoxic period. If the oxidized layer had been thinner, nitrification might have been more sensitive to anoxia. Therefore, it is not only the length of an anoxic period, but also the frequencies of such periods and the capacity of the sediment to recover between exposures to anoxia that regulate the nitrogen dynamics in seasonally anoxic sediments.

The changes observed in the $\mathrm{P}$ fractions were also likely to have been more pronounced in the manipulated sediments than in nature as the pre-treatment of the sediment and the effective oxidation in a closed system may have enhanced oxidation and mineralisation processes in general. In our experiments, a short exposure to anoxia quickly caused a release of dissolved $\mathrm{P}$ from the 2 most labile forms of $\mathrm{P}(\mathrm{NaCl}-\mathrm{iP}$ and NaBD-iP). The effect was highly reversible, which was also evident in the quickly decreasing concentrations of the $\mathrm{PO}_{4}{ }^{3-}$ in the water phase after oxic conditions were restored. As the replenishment of $\mathrm{O}_{2}$ stores in nature is usually linked to an intense mixing of the water column (e.g. turnover or upwelling events), P released during anoxia may reach the productive layer instead of being readsorped into sediment, even when $\mathrm{O}_{2}$ conditions are improved. However, in the oxic zone of the water column, dissolved $\mathrm{P}$ is rapidly bound to oxidized Fe-compounds (when Fe is present in sufficient concentration) and may settle with depositing particulates (e.g. Ellis-Evans \& Lemon 1989, Gunnars \& Blomqvist 1997, Gunnars et al. 2002). Furthermore, some of the organic $\mathrm{P}$ compounds participate in $\mathrm{P}$ cycling at the sediment-water interface over relatively short time scales and are affected by fluctuating $\mathrm{O}_{2}$ conditions (e.g. Gächter et al. 1988, Hupfer et al. 1995b, Törnblom \& Rydin 1998).

In a $\mathrm{N}$ limited ecosystem such as the Baltic Sea, a short exposure to anoxia may, according to our findings, further strengthen the $\mathrm{N}$ limitation by simultaneously enhancing $\mathrm{N}$ removal and increasing internal $\mathrm{P}$ loading. It has also been estimated that the eutrophied Baltic Sea has already entered a potentially selfsustaining vicious circle in which the increased nutrient availability enhances production and sedimentation of organic matter. Oxidation of this organic matter causes anoxia, leading to internal loading of $\mathrm{P}$ and a further lowering of the N:P ratio. The low N:P ratio, in turn, may lead to blooms of $\mathrm{N}$ fixing cyanobacteria, a common phenomenon in the eutrophied Gulf of Finland (Vahtera et al. 2007). Seasonal anoxia occurs in coastal areas when the increase in temperature both escalates the mineralisation rate of the organic matter and at the same time lowers $\mathrm{O}_{2}$ solubility. In the open 
sea sediments of the Gulf of Finland, temperature is rather stable year round, whereas $\mathrm{O}_{2}$ concentrations fluctuate with remarkable year-to-year variations due to the complicated hydrodynamic nature of the area (Alenius et al. 1998). In both coastal and open sea sediments, however, the key factor causing anoxia is the increased amount of sedimenting matter, which can only be reduced by reducing external nutrient loading to the Gulf.

Acknowledgements. This study was funded by the Academy of Finland and Finnish Ministry of Environment under the BIREME programme, and conducted through the SEGUE consortium.

\section{LITERATURE CITED}

Ahlgren J, Tranvik L, Gogoll A, Waldebäck M, Markides K, Rydin E (2005) Sediment depth attenuation of biogenic phosphorus compounds measured by ${ }^{31} \mathrm{P}$ NMR. Environ Sci Technol 39:867-872

Alenius P, Myrberg K, Nekrasov A (1998) The physical oceanography of the Gulf of Finland: a review. Boreal Env Res 3:97-125

Andersen FØ, Ring P (1999) Comparison of phosphorus release from littoral and profundal sediments in a shallow, eutrophic lake. Hydrobiologia 408/409:175-183

Bodelier PLE, Libochant JA, Blom CWPM, Laanbroek HJ (1996) Dynamics of nitrification and denitrification in rootoxygenated sediments and adaptation of ammonia-oxidizing bacteria to low-oxygen or anoxic habitats. Appl Environ Microbiol 62:4100-4107

Carlucci AF, McNally PM (1969) Nitrification by marine bacteria in low concentrations of substrate and oxygen. Limnol Oceanogr 14:736-739

Conley DJ, Humborg C, Rahm L, Savchuk OP, Wulff F (2002) Hypoxia in the Baltic Sea and basin-scale changes in phosphorus biogeochemistry. Environ Sci Technol 36: $5315-5320$

Dalsgaard T, Thamdrup B (2002) Factors controlling anaerobic ammonium oxidation with nitrite in marine sediments. Appl Environ Microbiol 68:3802-3808

Dalsgaard T, Thamdrup B, Canfield DE (2005) Anaerobic ammonium oxidation (anammox) in the marine environment. Res Microbiol 156:457-464

Davison W, Seed G (1983) The kinetics of the oxidation of ferrous iron in synthetic and natural waters. Geochim Cosmochim Acta 47:67-79

Drake JC, Heaney SI (1987) Occurrence of phosphorus and its potential remobilization in the littoral sediments of a productive English lake. Freshw Biol 17:513-523

Einsele W (1936) Über die Beziehungen des Eisenkreislaufs zum Phophatkreislauf im eutrophen See. Arch Hydrobiol 29:664-686

Ellis-Evans JC, Lemon ECG (1989) Some aspects of iron cycling in maritime Antarctic lakes. Hydrobiologia 172: 149-164

Gächter R, Meyer JS, Mares A (1988) Contribution of bacteria to release and fixation of phosphorus in lake sediments. Limnol Oceanogr 33:1542-1558

Goreau TJ, Kaplan WA, Wofsy SC, McElroy MB, Valois FW, Watson SW (1980) production of $\mathrm{NO}_{2}{ }^{-}$and $\mathrm{N}_{2} \mathrm{O}$ by nitrifying bacteria at reduced concentrations of oxygen. Appl
Environ Microbiol 40:526-532

Grasshoff K, Ehrhardt M, Kremling K (1983) Methods of seawater analysis, 2nd edn. Verlag Chemie, Weinheim

Gundersen K (1966) The growth and respiration of Nitrocystis oceanus at different partial pressures of oxygen. J Gen Microbiol 42:387-396

Gundersen K, Carlucci AF, Boström K (1966) Growth of some chemoautotrophic bacteria at different oxygen tensions. Experientia 22:229-230

Gunnars A, Blomqvist S (1997) Phosphate exchange across the sediment-water interface when shifting from anoxic to oxic conditions - an experimental comparison of freshwater and brackish-marine systems. Biogeochem 37:203-226

Gunnars A, Blomqvist S, Johansson P, Andersson C (2002) Formation of Fe(III) oxyhydroxide colloids in freshwater and brackish seawater, with incorporation of phosphate and calcium. Geochim Cosmochim Acta 66:745-758

Henriksen K, Kemp WM (1988) Nitrification in estuarine and coastal marine sediments. In: Blackburn TH, Sørensen J (eds) Nitrogen cycling in coastal marine environments. John Wiley \& Sons, Chichester, p 207-249

Hietanen S, Kuparinen J (in press) Seasonal and short-term variation in denitrification and anammox at a coastal station on the Gulf of Finland, Baltic Sea. Hydrobiologia doi 10.1007/s10750-007-9058-5

Hupfer M, Uhlmann D (1991) Microbially mediated phosphorus exchange across the mud-water interface. Verh Internat Verein Limnol 24:2999-3003

Hupfer M, Gächter R, Rüegger H (1995a) Polyphosphate in lake sediments: ${ }^{31} \mathrm{P}$ NMR spectroscopy as a tool for its identification. Limnol Oceanogr 40:610-617

Hupfer M, Gächter R, Giovanoli R (1995b) Transformation of phosphorus species in settling seston and during early sediment diagenesis. Aquat Sci 57:305-324

Hupfer M, Rübe B, Schmieder P (2004) Origin and diagenesis of polyphosphate in lake sediments: a ${ }^{31} \mathrm{P}-\mathrm{NMR}$ study. Limnol Oceanogr 49:1-10

Jensen HS, Thamdrup B (1993) Iron-bound phosphorus in marine sediments as measured by bicarbonate-dithionite extraction. Hydrobiologia 253:47-59

Jensen HS, Mortensen PB, Andersen FO, Rasmussen E, Jensen A (1995) Phosphorus cycling in a coastal marine sediment, Aarhus Bay, Denmark. Limnol Oceanogr 40: 908-915

Kemp WM, Sampou P, Caffrey J, Mayer M (1990) Ammonium recycling versus denitrification in Chesapeake Bay sediments. Limnol Oceanogr 35:1545-1563

Kester RA, de Boer W, Laanbroek HJ (1997) Production of NO and $\mathrm{N}_{2} \mathrm{O}$ by pure cultures of nitrifying and denitrifying bacteria during changes in aeration. Appl Environ Microbiol 63:3872-3877

Koroleff F (1983) Determination of phosphorus. In: Grasshoff K, Ehrhardt M, Kremling K (eds) Methods of seawater analysis, 2nd edn. Verlag Chemie, Weinheim, p 125-187

Krom MD, Berner R (1980) Adsorption of phosphate in anoxic marine sediments. Limnol Oceanogr 25:797-806

Laine AO, Sandler H, Andersin AB, Stigzelius J (1997) Longterm changes of macrozoobenthos in the Eastern Gotland Basin and the Gulf of Finland (Baltic Sea) in relation to the hydrographical regime. J Sea Res 38:135-159

Lukkari K, Hartikainen H, Leivuori M (in press) Fractionation of sediment phosphorus revisited: I Fractionation steps and their biogeochemical basis. Limnol Oceangr Methods 5

Millero FJ, Sotolongo S, Izaguirre M (1987) The oxidation kinetics of $\mathrm{Fe}(\mathrm{II})$ in seawater. Geochim Cosmochim Acta 51:793-801 
Mortimer CH (1941) The exchange of dissolved substances between mud and water in lakes, I. J Ecol 29:280-329

Mortimer CH (1942) The exchange of dissolved substances between mud and water in lakes, II. J Ecol 30:147-201

Nielsen LP (1992) Denitrification in sediment determined from nitrogen isotope pairing. FEMS Microbiol Ecol 86: $357-362$

Pitkänen H, Lehtoranta J, Räike A (2001) Internal nutrient fluxes counteract decreases in external load: the case of the estuarial eastern Gulf of Finland, Baltic Sea. Ambio 30: 195-201

Prosser JI (1989) Autotrophic nitrification in bacteria. Adv Microbiol Physiol 30:125-181

Psenner R, Pucsko R, Sager M (1984) Die Fraktionierung organischer und anorganischer Phosphorverbindungen von Sedimenten. Versuch einer Definition ökologisch wichtiger Fraktionen. Fractionation of organic and inorganic phosphorus compounds in lake sediments. An attempt to characterize ecologically important fractions. Arch Hydrobiol Suppl 70:111-155

Risgaard-Petersen N, Nielsen LP, Rysgaard S, Dalsgaard T, Meyer RL (2003) Application of the isotope pairing technique in sediment where anammox and denitrification coexist. Limnol Oceanogr Methods 1:63-73 + appendix

Risgaard-Petersen N, Nielsen LP, Rysgaard S, Dalsgaard T, Meyer RL (2004) Erratum: Application of the isotope pairing technique in sediment where anammox and denitrification coexist. Limnol Oceanogr Methods 2:315

Sohlenius G, Emeis KC, Andrén E, Andrén T, Kohly A (2001) Development of anoxia during the Holocene fresh-brackish water transition in the Baltic Sea. Mar Geol 177: $221-242$

Editorial responsibility: Frede Thingstad, Bergen, Norway
Thamdrup B, Dalsgaard T (2002) Production of $\mathrm{N}_{2}$ through anaerobic ammonium oxidation coupled to nitrate reduction in marine sediments. Appl Environ Microbiol 68: $1312-1318$

Törnblom E, Rydin E (1998) Bacterial and phosphorus dynamics in profundal Lake Erken sediments following the deposition of diatoms: a laboratory study. Hydrobiologia 364: 55-63

Trimmer M, Nicholls JC, Deflandre B (2003) Anaerobic ammonium oxidation measured in sediments along the Thames estuary. Appl Environ Microbiol 69:6447-6454

Tuominen L, Heinänen A, Kuparinen J, Nielsen LP (1998) Spatial and temporal variability of denitrification in the sediments of the northern Baltic Proper. Mar Ecol Prog Ser 172:13-24

Tuominen L, Mäkelä K, Lehtonen KK, Haahti H, Hietanen S, Kuparinen J (1999) Nutrient fluxes, pore water profiles and denitrification in sediment influenced by algal sedimentation and bioturbation by Monoporeia affinis. Estuar Coast Shelf Sci 49:83-97

Vahtera E, Conley DJ, Gustafsson BG, Kuosa H and others (2007) Internal ecosystem feedbacks enhance nitrogenfixing cyanobacteria blooms and complicate management in the Baltic Sea. Ambio 36:186-194

Voytek MA, Ward BB (1995a) Detection of ammoniumoxidizing bacteria of the beta-subclass of the class proteobacteria in aquatic samples with the PCR. Appl Environ Microbiol 61:1444-1450

Voytek MA, Ward BB (1995b) Detection of ammonium-oxidizing bacteria of the beta-subclass of the class proteobacteria in aquatic samples with the PCR. Appl Environ Microbiol 61:2811 (erratum)

Submitted: November 2, 2006; Accepted: September 6, 2007 Proofs received from author(s): November 19, 2007 